\title{
CAMERA BRANDING CALON WALIKOTA DI MEDIA SOSIAL (Studi Kasus Pilwakot 2015 Paslon Idris-Pradi)
}

\author{
Dina Andriana ${ }^{1}$, Widarti ${ }^{2}$, Jusuf Fadilah ${ }^{3}$ \\ Program Studi Periklanan, dina.daa@bsi.ac.id \\ Program Studi Periklanan, widarti.wdr@bsi.ac.id \\ Program Studi Periklanan, jusuf.jff@ bsi.ac.id
}

\begin{abstract}
This study discusses the case of camera branding conducted by the regional head candidate pair Idris-Pradi on social media as a campaign tool in obtaining votes in PILWAKOT DEPOK 2015. The study uses a qualitative approach with a constructivist paradigm, the nature of descriptive research with the case study research method from Yin. The forms of photo / camera branding can be seen from the use of shooting ranging from shooting, angle of view (angle) shooting, the type of lens used, the focal point used, lighting and prominent coloration in photographs. In addition, the camera branding element in the form of an authentic element and the unique element of the paslon profile also supports the level of electability. The use of photo / camera branding can have direct and indirect effects for voters. And voters in Depok are more of the majority of traditional voter types, although around 37.6\% of voters in Depok are of productive age.
\end{abstract}

Keywords: Camera Branding, Paslon, Depok Election.

\begin{abstract}
Abstrak
Penelitian ini membahas tentang kasus camera branding yang dilakukan paslon kepala daerah Idris-Pradi di media sosial sebagai alat kampanye dalam memperoleh suara pas PILWAKOT DEPOK 2015. Penelitian menggunakan pendekatan kualitatif dengan paradigma konstruktivis, sifat penelitian deskriptif dengan metode penelitian studi kasus dari Yin. Bentuk-bentuk foto/camera branding dapat dilihat dari penggunaan pengambilan gambar mulai dari pengambilan gambar, sudut pandangan (angle) pengambilan gambar, tipe lensa yang digunakan, titik fokus yang digunakan, pencahayaan serta pewarnaan yang menonjol dalam foto. Selain itu elemen camera branding berupa elemen authentic dan elemen keunikan profil paslon juga mendukung tingkat elektabilitas. Penggunaan foto/camera branding dapat menimbulkan efek langsung dan tidaklangsung bagi para pemilih. Dan pemilih di kota depok lebih kepada mayoritas tipe pemilih tradisional walaupun sekitar $37.6 \%$ pemilih di Kota Depok pada usia produktif.
\end{abstract}

Kata Kunci: Camera Branding, Paslon, Pilkada Depok.

\section{PENDAHULUAN}

Pemilihan kepala daerah (Pilkada) secara langsung membawa iklim demokrasi baru bagi perkembangan pendidikan politik di Indonesia, hal ini terjadi sejak adalanya perubahan Undang-Undang Nomor 22 tahun 1999, kemudian diubah menjadi Undang-undang no. 32 tahun 2004 tentang Pemerintahan Daerah. Implikasi dari perubahan undang-undang ini adalah adanya pemilu langsung yang diatur pada Pasal 56-119, tentang Pemilihan Kepada

ISSN: 2355-0287, E-ISSN: 2549-3299

http://ejournal.bsi.ac.id/ejurnal/index.php/jika 
Daerah dan Wakil Kepala Daerah, yang sebelumnya dipilih oleh DPRD I dan DPRD II.

Kemudian paska disahkannya UndangUndang no. 1 Tahun 2015, pelaksanaan Pilkada serentak di 269 daerah di Indonesia ada 9 Desember 2015. Pilkada serentak 2015 ini merupakan pilkada gelombang pertama dari tiga gelombang pilkada serentak yang akan diadakan. Proses pilkada diikuti dengan kegiatan kampanye. Kampanye adalah kegiatan menawarkan visi, misi dan program pasangan calon dan/atau informasi lainnya, yang bertujuan mengenalkan atau meyakinkan pemilih ${ }^{1}$.

Perubahan mekanisme pemilihan umum kepala daerah tersebut mengakibatkan perubahan pola fikir calon kepala daerah terhadap konsep kampanye yang harus dilakukan. Sebelum pemilihan secara langsung dan serentak, partai politiklah yang berperan dalam kampanye pilkada. Namun, pada pilkada serantak dan langsung di tahun 2015 ini, sosok calon lebih dipentingkan, karena rakyatlah yang menentukan pilihan. Sehingga konsep kampanye lebih kepada bagaimana merebut dan menarik simpati rakyat.

Pada pilkada serentak 2015, masingmasing tim kampanye balon (bakal calon) pemimpin daerah melakukan kampanye di segala lini komunikasi mulai dari media konvensional hingga media online dalam hal ini adalah media sosial. Peran media sosial seperti Facebook, Twitter, Forum Online, Blog, Youtube, dan Portal Berita Online sangat besar dalam kampanye pilkada 2015. Riset yang dilakukan oleh Salingsilang.com dan PoliticaWave,

\footnotetext{
${ }^{1}$ Peraturan KPU (PKPU) No. 70 Tahun 2015 tentang Pilkada Bab I Ketentuan Umum pasal 1, hal 5 .
}

lembaga pemantau media sosial dalam Pemilihan Gubernur DKI dengan hasil akhir Pilkada pun tak jauh berbeda. Lembaga itu menyatakan, aktivitas di jejaring sosial dapat memetakan siapa calon gubernur yang nantinya memenangi Pilkada.

Di negara-negara maju, seperti Amerika Serikat atau Jepang telah lama menerapkan sistem pilkada langsung. Negara-negara tersebut menerapkan suatu model kampanye yang bertujuan menarik simpati rakyat pada pasangan calon pemimpin dengan mengembangkan suatu model kampanye personal branding. Konsep ini menekankan pada cara-cara untuk mempersuasi rakyat selaku pemilih, agar memberikan suara kepada kandidat.

Barrack Obama misalnya telah membuktikan bahwa pencitraan dirinya di dunia maya melalui blogging dan social networking berhasil mengantarkannya menjadi orang nomor satu di Amerika Serikat. Di Indonesia, strategi personal branding juga dilakukan oleh Susilo Bambang Yudhoyono pada pemilihan presiden secara langsung di tahun 2004 dan 2009. Dapat disimpulkan bahwa politisi atau calon kepada daerah berupaya mengendalikan persepsi orang atau masyarakat seperti yang diinginkan.

Di Indonesia, pengguna media sosial memang terus tumbuh. Data Kementerian Komunikasi dan Informatika pada 2013 menunjukkan, setidaknya ada 63 juta pengguna internet di Indonesia. Sebanyak 95\% di antaranya menggunakan internet untuk mengakses situs jejaring sosial. Oleh karena itu, kemunculan ruang publik digital tersebut juga membuka kesempatan bagi politisi untuk berkampanye ${ }^{2}$.

${ }^{2}$ http://nasional.kompas.com/read/2015/09/25/1513 0071/Media.Sosial.Makin.Jadi.Primadona.Kampan ye.Pilkada. Diakses 11 Desember 2015.

ISSN: 2355-0287, E-ISSN: 2549-3299 
Kehadiran media sosial membuat masyarakat menjadi terbuka dan berani dalam bersuara satu sama lain di dunia maya. Dengan menggunakan komputer atau telepon pintar (smartphone) yang terhubung ke internet, masyarakat dapat menyuarakan aspirasinya. Pengguna media sosial bukan hanya didominasi oleh kelas menengah ke atas, kalangan menengah bawah juga mulai melek dan akrab dengan media sosial. Murahnya smartphone dan pulsa yang terjangkau ikut membantu menambah pengguna internet.

Media sosial memang menjadi salah satu fenomena dan memiliki daya tarik luar biasa di era demokrasi virtual dewasa ini, seperti Facebook dan Twitter. Bahkan

untuk pengguna Twitter, data pada Februari 2014 lalu menyebutkan, Indonesia menempati peringkat ketiga $(6,5 \%)$ di dunia setelah Amerika Serikat $(24,3 \%)$ dan Jepang $(9,3 \%)$ dan untuk pengguna Facebook menempati peringkat kedua dunia (41.777.240 dari total penduduk Indonesia sebanyak 241.452.952) ${ }^{3}$.

Menjelang penyelenggaraan Pilkada Serentak yang puncak perhelatannya digelar pada 9 Desember 2015, sejumlah Calon Kepala Daerah dan Wakil Kepala Daerah ramai-ramai menggunakan Medsos, baik petahana maupun kandidat pendatang baru. Dalam pencermatan Badan Pengawas Pemilu (Bawaslu), sebanyak 26\% dari 105 calon Kepala Daerah di 58 kabupaten dan kota menggunakan media sosial sebagai sarana kampanye. Dari jumlah itu, sebanyak 57\% menggunakan Facebook dan 27\%

\footnotetext{
${ }^{3}$ http://www.bawaslu-

dki.go.id/13/10/2015/kampanye-pilkada-di-mediasosial/ . diakses 11 Desember 2015.
}

menggunakan Twitter. Bahkan pada sejumlah provinsi yang akan menggelar Pilkada Serentak gelombang kedua (2017), sudah banyak yang memanfaatkan media sosial sebagai bahan pencitraan diri dan kampanye terselubung (sosialisasi).

Ada banyak pertimbangan, mengapa media sosial kini banyak dilirik oleh para kandidat sebagai instrumen kampanye politik. Diantaranya, sebagaimana dikatakan Douglas Hagar (2014) dalam "Compaigning Online: Social Media in the 2010 Niagara Municipal Elections", karena media sosial bisa berkontribusi pada keberhasilan politik. Ini karena media sosial membuat kandidat dalam sebuah pemilihan bisa berinteraksi dengan para calon pemilih dengan skala dan intensitas yang tak bisa dicapai lewat pola kampanye tradisional seperti kampanye dari pintu ke pintu, brosur, bahkan peliputan media cetak dan televisi. Selain itu, biaya kampanye media sosial juga jauh lebih murah karena tidak ada biaya yang langsung diasosiasikan dengan media sosial sosial semacam Facebook, Twitter, dan Youtobe. (Kompas, 25 September 2015) ${ }^{4}$.

Personal branding merupakan strategi komunikasi untuk memasuki jendela otak pemilih agar seorang kontestan memiliki makna tertentu yang mencerminkan keunggulan terhadap kontestan pesaing dalam bentuk hubungan asosiatif. Dengan personal branding maka pemilih yang semula tidak bersimpati menjadi bersimpati, dari yang tidak peduli menjadi peduli. Personal branding efektif untuk memperkuat dukungan masyarakat dan meningkatkan elektabilitas (Nursal, 2004).

ISSN: 2355-0287, E-ISSN: 2549-3299

http://ejournal.bsi.ac.id/ejurnal/index.php/jika 
Personal branding makin marak ditemukan saat kampanye pilkada berlangsung. Berbagai bentuk visual kampanye politik pilkada dilakukan oleh tim sukses paslon kepala daerah, mulai dari penggunaan kampanye di media massa konvensional hingga ke media massa kontemporer yaitu media sosial. Proses penggunaan media massa yang menampilkan visualisasi baik berupa gambar gerak atau pun diam ini merupakan contoh proses yang disebut camera branding dalam prinsip personal branding.

Usaha-usaha yang dilakukan secara sengaja oleh tim sukses partai politik atau paslon kepala daerah untuk membentuk dan mengubah sikap masyarakat dengan menggunakan media komunikasi dengan tujuan menjaring masyarakat untuk memilih merupakan suatu bentuk dari propaganda. Dan camera branding menjadi alat dalam melakukan personal branding yang merupakan bentuk dari propaganda.

Penerapan camera branding banyak dilakukan oleh paslon kepala daerah pada Pilkada langsung dan serentak di tahun 2015. Salah satu pemilihan yang menarik dan menjadi perhatian adalah pemilihan paslon walikota dan wakil walikota Depok. Pasangan nomor urut satu, Dimas Oky Nugroho dan Babai Suhaimini yang didukung PDI-P, PKB, PAN, Nasdem, dan Golkar. pasangan nomor urut dua, Idris Abdul Shomad dan Pradi Surpriyatna. Mereka mendapat dukungan dari PKS, Gerindra, dan Demokrat.

Berdasarkan survei sementara yang dilakukan Indobarometer, yang meneliti sebelum pencoblosan, pasangan Idris Pradi merupakan kandidat yang tinggi populeritasnya. Hasil survei menunjukkan bahwa Indris-Pradi mendapatkan 30\% tingkat elektabilitas dan pasangan Dimas

- Babai meraih 17\% tingkat elektabilitas 5 .

Namun penulis hanya akan membahas camera branding sebagai alat kampanye yang dilakukan paslon Walikota dan Wakil Walikota Depok Idris - Pradi dalam upaya vote getter pada pilkada langsung dan serentak di tahun 2015.

\section{KAJIAN LITERATUR Political Marketing}

Political marketing adalah suatu model kampanye untuk menarik simpati rakyat dalam Pemilu. Political marketing juga diartikan strategi kampanye politik untuk membentuk serangkaian makna politis tertentu di dalam pikiran para pemilih (Nursal, 2004). Istilah marketing pada mulanya adalah konsep yang sering digunakan di dalam dunia bisnis. Dalam tulisan Newman dan Perloff dalam Prisgunanto (2006), dikatakan bahwa pemasaran politik didefinisikan sebagai aplikasi prinsip-prinsip pemasaran dalam kampanye politik yang beraneka ragam indiviu, organisasi, prosedur-prosedur dan melibatkan analisis, pengembangan, eksekusi, dan strategi manajemen kampanye oleh kandidat, partai politik, pemerintah, pelobi, kelompok-kelompok tertentu yang bisa digunakan untuk mengarahkan opini publik pada ideologi mereka.

Dalam marketing politik yang ditekankan adalah penggunaan pendekatan dan metode marketing untuk membantu politikus dan partai politik agar lebih efisien serta efektif dalam membangun hubungan dua arah dengan konstituen.

\footnotetext{
${ }^{5}$ http://www.depoknews.id/unggul-survei-pilkadadepok-pradi-bersyukur/ diakses 18 Desember 2015.
} 
Penerapan prinsip marketing meluas ke luar institusi bisnis di negara-negara maju.

\section{Strategi Marketing}

Marketing politik juga menyediakan perangkat teknik dan metode marketing dalam dunia politik (Firmanzah, 2012) dalam proses political marketing digunakan penerapan 4Ps merketinng, yaitu:

\section{a. Produk (Product)}

Berupa partai, kandidat dan gagasangagasan partai yang akan disampaikan konstituen produk berisi konsep, identitas ideologi. Baik dimasa lalu maupun sekarang, yang berkontribusi dalam pembentukan sebuah produk politik.

b. Harga (Price)

Mencakup banyak hal, baik ekonomi, psikologis, sampai citra nasional. Harga ekonomi mencakup semua biaya yang dikeluarkan partai selama periode kampanye. Harga psikologis mengacu pada harga persepsi psikologis misalnya, pemilih merasa nyaman, dengan latar belakang etnis, agama, pendidikan dan lain-lain. Sedangkan harga citra nasional berkaitan dengan apakah pemilih merasa kandidat tersebut dapat memberikan citra positif dan dapat menjadi kebanggaan negara.

\section{c. Tempat (Place)}

Berkaitan erat dengan cara hadir atau distribusi sebuah partai dan kemampuannya dalam berkomunkasi dengan para pemilih. Ini berarti sebuah partai haruis dapat memetakan struktur serta karakteristik masyarakat baik itu geografis maupun demografis.

d. Promosi (Promotion)

Upaya periklanan, kehumasan, dan promosi pendukung lainnya untuk mendukung sebuah partai yang di-mix sedemikian rupa sesuai dengan kebutuhan masyarakat. Dalam hal ini, pemilihan media perlu dipertimbangan.

e. Segmentasi

Upaya untuk mengenal kelompokkelompok pasar. Selain itu bisa digunakan untuk pemilahan kategori atau kelompok, berguna untuk mencari peluang, merumuskan pesan komunikasi, melayani lebih baik, menganalisis perilaku konsumen, mendesain produk. Menguasi konsep pemilahan kelompok masyarakat pemilih sangat diperlukan bagi calon kepala daerah karena masyarakat sangat heterogen. Jika calon kepala daerah memahami karakter segmen yang menjadi sasaran pemilihan dengan baik bisa memberikan tawaran politik yang lebih efektif untuk mendongkrak elektabilitas.

Penggunaan 4Ps marketing dalam dunia politik menjadikan marketing politik tidak hanya sebatas masalah iklan, tetapi lebih komprehensif. Marketing politik menyangkut cara sebuah institusi politik atau parpol atau kandidat ketika memformulasikan produk politik, menyusun program publikasi kampanye dan komunikasi politik, strategi segmentasi untuk memenuhi kebutuhan lapisan masyarakat sampai keperhitungan harga sebuah produk politik (Firmanzah, 2012).

Inti dari political marketing adalah mengemas pencitraan, publik figur dan kepribadian (personality) seorang kandidat yang berkompetisi dalam konteks pemilihan umum kepada masyarakat luas yang akan memilihnya. (Prisgunanto, 2006).

Tujuan marketing dalam politk adalah membantu kandidat untuk lebih baik 
dalam mengenal masyarakat yang diwakili atau menjadi target dan kemudian mengembangkan isu politik yang sesuai dengan aspirasi mereka.

Pemasaran politik dikenal adanya publisitas politik. Publisitas merupakan upaya mempopulerkan diri kandidat atau institusi partai yang bertarung. Menurut Kotler dan Neil dalam Newman (1999), ada 4 (empat) bentuk publisitas yang dikenal dalam komunikasi politik, yaitu:

1. Dikenal sebagai pure publicity yakni mempopulerkan diri melalui aktivitas masyarakat dengan setting social yang natural atau apa adanya. Misalnya saja, bulan Ramadhan dan Idul Fitri yang merupakan siklus aktivitas tahunan sehingga menjadi realitas yang apa adanya. Kandidat bisa memanfaatkan kesempatan tersebut untuk memasarkan dirinya. Misalnya dengan mengucapkan "Selamat menjalani Bulan Ramadhan" atau "Selamat Tahun Baru" dengan disertai nama atau foto kandidat. Semakin banyak jenis bentuk pure publicity yang digarap, maka akan semakin populer kandidat.

2. Free ride publicity yakni publisitas dengan cara memanfaatkan akses atau menunggangi pihak lain untuk turut mempopulerkan diri. Misalnya dengan tampil menjadi pembicara di sebuah forum yang diselenggarakan pihak lain, menjadi sponsor gerakan anti narkoba, turut berpartisipasi dalam pertandingan olahraga di sebuah daerah pemilihan.

3. Tie in publicity yakni dengan memanfaatkan extra ordinary news (kejadian sangat luar biasa). Misalnya peristiwa tsunami, gempa bumi atau banjir bandang. Kandidat dapat mencitrakan diri sebagai orang atau partai yang memiliki kepedulian sosial yangtinggi sehingga imbasnya memperoleh simpata khalayak. Sebuah peristiwa luar biasa, dengan sendirinya memikat media untuk meliput. Sehingga partisipasi dalam peristiwa semacam itu, sangat menguntungkan kandidat.

4. Paid publicity yaitu mempopulerkan diri lewat pembelian rubrik atau program di media massa. Misalnya, pemasangan advertorial, iklan spot, iklan kolom, display, atau pun juga blocking time program di media massa.

Nursal (2004) mengemukakan beberapa tahap respon pemilih terhadap stimulasi, yaitu:

a. Awareness, yakni bila seorang dapat mengingat atau menyadari bahwa sebuah pihak tertentu merupakan kontestan Pemilu. Dengan jumlah kontestan Pemilu yang banyak, membangun awareness cukup sulit dilakukan, khususnya bagi partaipartai baru. Seperti sudah menjadi hukum besi political marketing, secara umum para pemilih tidak akan menghabiskan waktu dan energinya untuk menghapal nama kontestan tersebut. Yang jelas seorang pemilih tidak akan memilih kontestan yang tidak memiliki brand awareness.

b. Knowledge, yakni ketika seorang pemilih mengetahui beberapa unsur penting mengenai produk kontestan tersebut, baik substansi maupun presentasi. Unsur-unsur itu akan diinterpretasikan sehingga membentuk makna politis tertentu dalam pikiran pemilih. Dalam pemasaran produk komersial, tahap ini disebut juga sebagai tahap pembentuk brand association dan perceived quality.

c. Liking, yakni tahap di mana seorang pemilih menyukai kontestan tertentu karena satu atau lebih makna politis 
yang terbentuk dipikirannya sesuai dengan aspirasinya.

d. Preference, tahap dimana pemilih menganggap bahwa satu atau beberapa makna politis yang berbentuk sebagai intepretasi terhadap produk politik kontestan, tidak dapat dihasilkan secara lebih memuaskan oleh kontestan lainnya. Dengan demikian, pemilih tersebut memiliki kecenderungan untuk memilih kontestan tersebut.

e. Conviction, pemilih tersebut sampai pada keyakinan untuk memilih kontestan tertentu.

\section{Branding}

Blair \& Scammell (2007), mengemukakan bahwa "The permanent campaign focuses on the instruments of media politics; the brand concept uncovers the underlying strategic concerns of efforts to maintain voter loyalty through communication designed to provide reassurance, uniqueness (clear differentiation from rivals), consistency of values, and emotional connection with voters' values and visions of the good Life".

Branding adalah ciri khas pada generasi milenium dan digunakan oleh politisi dalam platform membangun citra. Politisi didorong untuk "menganggap diri mereka sebuah merek" dan menggunakan strategi public relation untuk menarik hati masyarakat (Blair \& Scammell, 2007).

\section{Personal Branding}

Nursal (2004), membagi formula untuk membentuk personal branding yang kuat. Personal branding yang kuat membutuhkan perencanaan prospek siapa saja dan di mana saja seseorang memberikan layakan. Artinya kandidat pesangan calon walikota dan wakil walikota siap memberikan layanan untuk masyarakat. Target market ini bisa berupa lokasi secara geografis, lifesyle, pendapatan, gender, pekerjaan dan umur. Hal yang lain yang dibutuhkan dalah pasangan calon walikota dan wakil walikota yang membangun personal branding harus menjadi spesialis dalam bidang yang dikuasai. Hal ini biasa dilakukan orang adalah ingin menjadi serba bisa dalam segala hal. Hal itu sama sekali tidak mendukung personal branding. Kemudian visibility selalu menjaga ingatan target khayalak sasaran agar selalu eksis, hal penting berikutnya dalam mendukung personal branding adalah memuaskan klien, pemuasan klien ini umumnya didapat dari totalitas yang diberikan dalam mengerjakan spesialisasi tersebut.

Personal branding didasarkan atas nilainilai kehidupan seseorang dan memiliki relevansi tertinggi terhadap siapa sesunguhnya diri seseorang. Juga merupakan merek pribadi seseorang, di benak semua orang yang dikenal. Personal branding akan membuat semua orang memandang seseorang secara berbeda dan unik, orang mungkin akan lupa dengan wajah seseorang, namun merek pribadi akan selalu diingat orang lain. Konsistensi merupakan prasyarat utama dari personal branding yang kuat. Hal-hal yang tidak konsisten akan melemahkan personal branding, dimana pada akhirnya akan menghilangkan kepercayaan serta ingatan orang lain terhadap diri anda (McNally \& Speak, 2002) dalam (Widyastuti, Wiloso, \& Herwandito, 2017).

\section{Picture/Photo Branding}

Istilah fotografi pertama kali dikemukaan oleh ilmuan Inggris, Sir John Herschell pada tahun 1839. Fotografi berasal dari kata photos (sinar/cahaya) dan graphos (mencatat/melukis), secara harfiah fotografi berarti mencatat atau melukis 
dengan sinar atau dengan cahaya (Darmawan, 2009).

Fotografi berarti proses atau metode untuk menghasilkan gamabr atau foto dari suatu objek dengan merekam pantulan cahaya yang mengenai objek tersebut pada media yang peka cahaya.

Sebuah foto bisa memiliki nilai yang sama dengan ribuan kata-kata, juga mampu untuk memikat perhatian. Foto bisa berdiri sendiri dan mudah dipahami sebagai simbol yang mudah dikenal. Pembuatan foto dimaksudkan untuk mendukung suatu pemahaman riil yang diungkapkan melalui berbagai bentuk gambar (Kusrianto, 2007).

Pengambilan foto dalam melakukan photo branding merupakan elemen yang paling penting, karena tahap ini akan menentukan bagaimana akhir terciptanya foto seperti yang dikehendaki, yaitu:

1. Long shot, pengambilan foto yang dilakukan secara longshot menggambarkan wilayah yang luas, seolah diambil dari jarak yang sangat jauh, pengambilan foto membuat subjek menjadi bagian kecil saja dari yang ditampilkan dalam gambar, kesan yang muncul adalah subjek menjadi tidak berarti.

2. Medium shot, bentuk subjek yang ditampilkan ukurannya sama dengan objek yang menjadi latar belakang. Dengan kata lain ukuran fotonya lebih kurang sama dengan ukuran latar belakang. Kesan yang nampak dari foto semacam ini adalah foto personal.

3. Close up, pengambilan foto close up, subjek lebih menonjol dibanding latar belakang, kesan yang muncul adalah intim dan dekat, masyarakat diajak untuk lebih memperhatikan subjek.
4. Superclose Up, subjek yang diambil dengan gambar yagn super besar tapi juga detail.

Pengambilan foto yang paling penting adalah menentukan sudut atau angle. Sudut pengambilan photo branding bukan hanya persoalan teknis tapi bisa memberikan makna pada gambar dan menghasilkan penafsiran yang berbeda dari masyarakat pemilih yang melihatnya, sudut pengambilan gambar atau angle dibagi menjadi tiga, yaitu:

5. Low angle, membuat subjek menjadi lebih tinggi dari mata yang memandang, kesan yang muncul dari sudut ini adalah kandidat terkesan lebih powerfull, lebih otoritatif, bila dibandingkan dengan sudut normal mata memandang.

6. High Shot, mengambil gambar dari atas subjek lebih power full, namun subjek terkesan seolah terlihat lebih pendek.

7. Eye level shot, memposisikan subjek dengan memotret sama sejajar, kesan yang muncul baik yang memandang maupun yang dilihat kedudukannya adalah sama, kesan yang ditimbulkan lebih natural.

\section{Camera Branding}

Kasali (2013), mengemukakan bahwa Camera branding adalah citra yang khas dari seseorang/lembaga yang terekspos di kamera televisi. Citra seseorang di televisi tentu mempengaruhi penilaian khayalak luas mengenai dirinya. Camera branding menjadi sesuatu yang penting bagi seseorang dan wajib dijaga baik - baik, terlebih karena camera branding inilah yang merupakan citra yang diketahui khalayak luas.

Camera branding melahirkan dua istilah karakteristik: cameragenic dan auragenic. Cameragenic adalah sebuah keunikan 
orang yang membuatnya tampak menyenangkan ketika dilihat orang banyak. Sementara itu auragenic adalah keunikan seseorang yang membuat orang tersebut mampu membuat orang lain feel good hanya dengan melihat dirinya, atau mendengarkan kata - katanya, dan lain sebagainya. Sebagai contoh, seorang aktris tentu lebih menonjolkan sifat cameragenic nya agar dapat digemari penonton televisi di berbagai belahan dunia, namun belum tentu memiliki sifat auragenic. Contohnya politisi seperti Jokowi, tentu tidak cameragenic - kurus, muka kurang ganteng, dan lain sebagainya. Namun ia memiliki sifat auragenic, karena kehadirannya selalu didambakan penduduk DKI Jakarta.

Berikut penjelasan elemen yang harus diperhatikan dalam membangun camera branding, yaitu:

1. Authentic Camera branding mungin tertarik dengan peniru-peniru yang menimbulkan kelucuan, namun camera branding tak memberi ruang pada para peniru. Peniru hanya punya sekali kreativitas, yaitu sekali jepret. Sedangkan mereka yang memegang legitimasi aunthentic akan selalu memunculkan hal-hal yang mengejutkan, karena branding adalah sebuah "creative expression" (Kasali, 2013).

2. Keunikan Dalam personal camera branding, keunikan diri bisa ditemukan dalam konten, apa yang dimiliki sebagai suatu yang sangat dikuasai. Konten (isi) bukanlah container (pembungkus), yaitu bidang yang menjadi keahlian, kekuatan, profesi, atau perhatian (Kasali, 2013). Keunikan yang berasal dari apa yang dimiliki sendiri akan lebih mudah dikembangkan, diceritakan, disiapkan dalam multikamera, karena tidak pernah habis-habisnya untuk disajikan kembali. Keunikan melahirkan diferensiasi, sekaligus perhatian dan kehormatan. Keunikan diri lahir dari proses pembentukan diri.

Keunikan diperkaya oleh hal yang bersifat intangibles, karena intangibles menimbulkan persepsi dan tasa, ia bersifat tetap dan melekat pada manusia (pikiran, perasaan dan tindakan), sehingga tidak dapat diperoleh dalam waktu singkat, tidak dapat dibeli dengan uang. Tokoh atau publik figure disukai bukan karena kekuatan fungsionalnya, melainkan kekuatan persepsinya yang membentuk intangibles aspek. Intangibles aspek adalah reputasi, image, kepercayaan, keahlian, keterampilan, budaya korporat, teamwork, kemampuan bekerja cepat, dan leadership yang semua itu membentuk rasa disukai. (Kasali, 2013).

\section{Elektabilitas}

Elektabilitas diartikan sebagai pengukur tingkat keterampilan paslon kepala daerah. Elektabilitas masyarakat tidak terlepas dari media termasuk dalam hal politk. Hubungan antara media dan politik dapat dilihat sebagai suatu hal yang sangat menarik, terutama ketergantungan antara sumber berita dengan pihak yang diberitakan (Cangara, 2009).

Elektabilitas dan popularitas memiliki hubungan yang sangat erat, sepasang calon kepala daerah yang tidak popular tasanya sulit untuk bisa mendapat dukungan yang luas. Tetapi untuk meyakinkan sepasang calon kepala daerah bahwa untuk menjadi kepala daerah tidak hanya harus populer tapi juga harus dipilih, memerlukan waktu sosialisasi yang cukup lama, pembangunan jaringan dan persiapan finansial yang matang.

\section{Efek Media Massa}


Terdapat empat model efek media (Perse, 2000) yaitu:

1. Direct effects atau efek langsung yaitu efek komunikasi yang secara langsung

2. Conditional effects (varying according to social and psychological factors)

3. Commulative effect (gradual and long term)

4. Cognitive-transactional (with particular reference to schema and framing)

Efek juga data berlangsung dalam jangka pendek dan jangka panjang, sebagaimana penjelasan dibawah ini :

1. Shot Term Effect yaitu efek jangka pendek yang berlangsung pada individu, group dan yang bersifat cepat dan sementara. Misal : opini mengenai kasus politik. Opini mengenai Partai Demokrat yang selama tahun 2011 mengalami banyak kasus yang disinyalir melibatkan kader PD sehingga opini masyarakat menjadi cederung negative yang hal itu dapat dilihat dari hasil penelitian beberapa lembaga penelitian politik yang menggambarkan turunnya popularitas dan kepercayaan terhadap SBY dan Partai Demokrat.

2. Long term effect yaitu efek komunikasi/komunikasi massa yang bersifat halus dan tersebar terhadap perilaku yang seolah-olah kurang diterima pengaruhnya,

\section{METODE PENELITIAN}

Paradigma penelitian ini adalah menggunakan paradigma konstruktivis. Paradigma konstruktivis, yaitu paradigma yang hampir merupakan antitesis dari paham yang meletakkan pengamatan dan objektivitas dalam menemukan suatu realitas atau ilmu pengetahuan. Paradigma ini memandang ilmu sosial sebagai analisis sistematis terhadap socially meaningful action melalui pengamatan langsung dan terperinci terhadap perilaku sosial yang bersangkutan menciptakan dan memelihara atau mengelola dunia sosial mereka (Hidayat, 2003).

Selain itu penelitian ini menggunakan pendekatan kualitatif dimana peneliti berusaha menginterpretasikan dan menjelaskan suatu fenomena secara holistik dengan menggunakan kata-kata, tanpa harus bergantung pada sebuah angka (Moleong, 2011).

Sifat penelitian deskriptif, dimana penelitian diuraikan secara deskriptif sistematis, faktual, dan akurat dengan fakta-fakta dan sifat-sifat populasi atau objek tertentu (Kriyantono, 2006).

Metode penelitian yang digunakan studi kasus dari Robert K. Yin di mana Tipe penelitian yang dilakukan merupakan studi eksplanatoris mengenai proses konstruksi suatu pesan kampanye melalui Photo/camera branding dari Kasali (2013). Pertanyaan "bagaimana" dan "mengapa" pada dasarnya lebih kepada studi kasus eksplanatoris. (Yin, 2011).

Desain penelitian yang menunjukkan desain kasus tunggal dengan satu unit analisis yaitu tipe 1, karena pada penelitian ini akan menganalisa proses branding yang terjadi akibat konstruksi Photo Paslon Walikota dan Wakil Walikota Depok Idris-Pradi.

\section{PEMBAHASAN}

Camera branding paslon Walikota dan Wakil Walikota Idris - Pradi di Media Sosial sebagai alat kampanye dalam upaya vote getter pada PILWAKOT Depok 2015. Dalam situsnya www.idrispradi.com dan account facebook serta twiternya terpampang beberapa gambar (picture/camera branding). Berikut akan dijelaskan 
masing-masing gambar (picture) branding yang digunakan paslon Idris-Pradi pada PILWALKOT 2015.

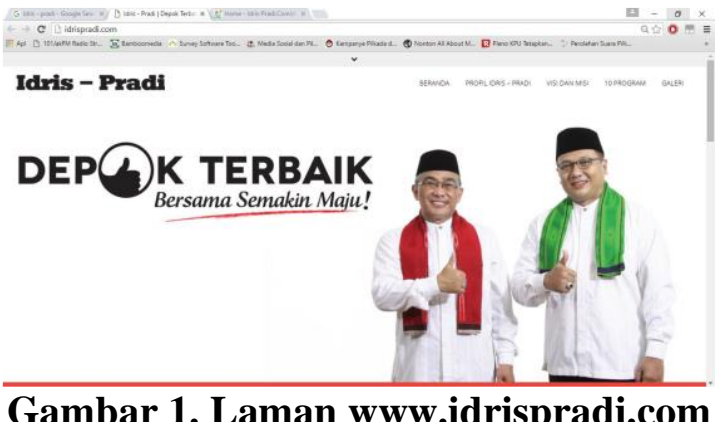

Pada laman ini berisi tentang profil Idris dan Pradi, visi misi, penjabaran 10 program kerja dan galeri yang berisi photo dan video kegiatan yang dilakukan selama masa kampanye.

Tata letak pada laman idrispradi.com dapat dikategorikan sederhana dimana warna latar putih lebih dominan. Sosok Idrus dan Pradi yang menggunakan baju "koko" putih terlihat membaur dengan warna latar laman. Kemudian terdapat slogan kampanye yang bertuliskan DEPOK TERBAIK Bersama Semakin Maju! Dengan menggunakan warna hitam. Pada tulisan DEPOK, huruf $\mathrm{O}$ disimbolkan berupa jari jempol mengacung yang berarti baik atau terbaik. Warna hitam yang digunakan pada tulisan slogan berarti independen, tegas dan kuat. Tim kampanye Idris-Pradi berusaha membranding paslonnya sebagai pribadi yang independen, kuat dan tegas dalam bersikap dan mengambil keputusan. Kemudian slogan tersebut dipertegas lagi dengan garis bawah berwarna merah yang menegaskan bahwa kata-kata bersama kita maju dengan tanda seru (!) adalah katakata yang penting sebagai janji (promise) Idris-Pradi kepada pemilihnya.

Lanjut kepada foto Idris dan Pradi. Pertama, sosok Idris menggunakan baju koko putih dengan berkalungkan sarung berwana merah dan berpeci hitam. Idris yang memang seorang kyai difigurkan secara "apik" dengan atribut-atribut bernuansa Islami seperti baju koko, peci dan sarung yang biasanya dipergunakan oleh muslim beribadah. Selain itu Idris juga merupakan salah satu tokoh ulama berpengaruh di Depok. Idris bernama lengkap DR. H. M. IDRIS ABDUL SHOMAD, MA. Beliau aktif di Lembaga Pelayanan Pesantren dan Studi Islam (LP2SI) Al Haramain dan aktif sebagai dosen di Fakultas Dakwah Pasca Sarjana UIN dan UI serta aktif pada Ikatan Da'i Indonesia (IKADI) menjadi Sekjen IKADI. Sedang sarung berwarna merah yang digunakan Idris merupakan lambang perkawinan dua calon yang didukung oleh partai PKS dan Gerindra. Idris menggunakan sarung berwarna merah yang merupakan warna dominan pada partai politik Gerindra.

Gesture Idris pada laman idrispradi.com difigurkan sebagai pribadi yang ramah tergambar pada senyuman dengan gigi terlihat di wajah Idris dan posisi tangan mengacungkan jempol yang memperkuat slogan DEPOK TERBAIK. Dan posisi Idris berada di sebelah kanan menyiratkan sebagai simbolisasi pemimpin.

Kedua, sosok Pradi menggunakan baju koko putih, berpeci hitam dan berkalungkan sarung berwarna hijau. Pradi yang bernama lengkap Pradi Supriatna seorang pengusaha muda sukses di bidang kelapa sawit. Beliau merupakan Ketua DPC Partai Gerindra kota Depok periode 2010-2015 dan tercatat sebagai ESCO PSSI Kota Depok. Pradi mewakili sosok pemuda yang membangun Depok menjadi lebih baik. Tim Sukses memfigurkan Pradi sebagai tokoh muda yang taat beribadah dengan perlambangan baju koko dan peci hitam sedangkan sarung berwarna hijau melambangkan 
perkawinan dua parpol PKS dan Gerindra. Sosok Pradi dikawinkan dengan Idris yang berasal dari PKS yang merupakan partai berlandaskan Islam yang akrab dengan simbolisasi warna hijau.

Jika ditinjau dari teknik pengambilan gambar pada laman idrispradi.com, foto Idris dan Pradi dapat dijabarkan sebagai berikut:

1. Pengambilan gambar Medium Shot, yang menandakan hubungan personal antara subjek foto dan audiens foto terlihat dekat,

2. Sudut pandangan (angle) pengambilan gambar Eye level yang menandakan kesejajaran, kesamaan dengan audiens.

3. Tipe lensa yang digunakan normal lens yang menandakan kebersahajaan dan keseharian yang tampak tanpa dibuat-buat.

4. Fokus yang digunakan tidak terlihat karena peleburan latar warna putih dengan foto meniadakan titik fokus.

5. Pencahayaan menggunakan high key dan low kontras yang menandakan keceriaan serta realistik karena berusaha menampilkan kesederhanaan figur Idris dan Pradi.

6. Pewarnaan yang menonjol adalah putih di mana putih melambangkan realisme dan faktual.

\section{Foto di Media Sosial Facebook \& Twitter}

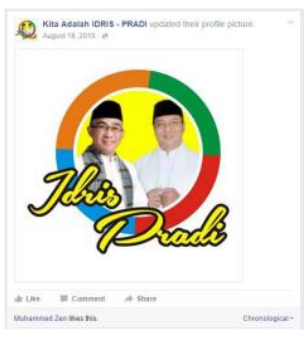

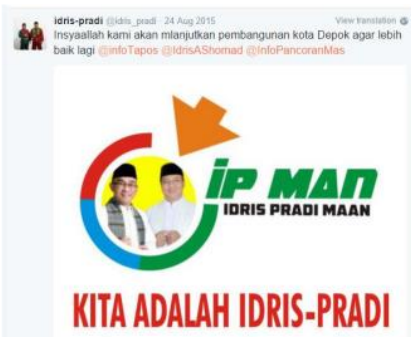

\section{Gambar 2. Foto Paslon Idris-Pradi di Media Sosial}

Foto pada media sosial Idris-Pradi di Facebook dan Twitter menggunakan sumber foto yang sama. Terdapat dua foto yang berbeda diseleksi dan dipotong kemudian digabungkan menjadi satu menggunakan software disain. Kemudian foto tersebut diberi latar kuning dan diberikan bingkai (frame) melingkar dengan kombinasi warna hijau, merah, biru dan orange. Sedikit variasi dilakukan pada foto di account twiter dengan penambahan tanda panah berwarna orang dan tulisan hijau dengan kata-kata IP Man.

Pertama, foto pada account FB, pada foto Idris dan Pradi menggunakan baju koko putih, peci hitam dan menggunakan sarung yang dikalungkan ke leher. Idris yang memang seorang kyai difigurkan secara "apik" dengan atribut-atribut bernuansa Islami seperti baju koko, peci dan sarung yang biasanya dipergunakan oleh muslim beribadah. Dan Pradi sebagai tokoh muda yang taat beribadah dengan perlambangan baju koko dan peci hitam. Kemudian penggunaan warna merah, hijau, biru dan orange merupakan perwakilan dari warna-warna yang melambangkan partai politik yang mendukung pasangan calon walikota dan wakil walikota Idris-Pradi yaitu Gerindra yang identik dengan merah, NU yang identik dengan warna hijau, Biru yang identik dengan warna Demokrat dan Orange yang identik dengan warna partai 
PKS. Posisi bingkai melingkar berwarna biru, merah, orange dan hijau melambangkan bahwa paslon dibawah naungan partai koalisi yang bertujuan memenangkan pasangan calon Walikota dan Wakil Walikota Idris-Pradi.

Kedua, foto pada account twitter @idris_pradi, merupakan foto yang sama dipakai padai account FB yang berbeda hanya pada tampilan atribut panah berwarna orange dan tulisan dengan katakata IP Man. Panah berwarna orange merupakan perlambangan cursor dimana pilihan akan ditekan (klik) dan kata-kata IP Man berarti singkatan dari Idris dan Pradi sedang kan kata Man berarti Relawan pendukung Idris dan Pradi. Makna warna yang digunakan masih sama seperti makna warna pada accont FBnya. Tinjauan dari teknik pengambilan gambar pada account FB dan Twiter, foto Idris dan Pradi dapat dijabarkan sebagai berikut:

1) Pengambilan gambar Medium Shot, yang menandakan hubungan personal antara subjek foto dan audiens foto terlihat dekat,

2) Sudut pandangan (angle) pengambilan gambar Eye level yang menandakan kesejajaran, kesamaan dengan audiens.

3) Tipe lensa yang digunakan normal lens yang menandakan kebersahajaan dan keseharian yang tampak tanpa dibuat-buat.

4) Fokus yang digunakan selective focus dimana foto menandai adanya permintaan perhatian tertuju pada objek Idris dan Pradi..

5) Pencahayaan menggunakan high key dan low kontras yang menandakan keceriaan serta realistik karena berusaha menampilkan kesederhanaan figur Idris dan Pradi.

6) Pewarnaan yang menonjol adalah warna hangat (warm) yaitu merah, oranye, hijau, dan biru yang menandai adanya optimisme dan harapan sosok figur Idris dan Pradi.

Sedangkan elemen pembentuk camera branding menurut Kasali (2013:50-55) pada foto dilaman www.idrispradi.com dapat dijelaskan sebagai berikut:

1) Authentic

Authentic disini berarti sesuatu apa adalanya tanpa dibuat-buat, sehingga apapun hasilnya akan dipercaya, dalat diandalkan, tulus, berasal dari hati, pikiran dan kesadaran diri.

Sosok Idris dan Pradi telah ditonjolkan secara authentik tidak dibuat-buat, penggambaran sosok dengan berbagai atribut seperti baju koko, peci hitam dan sarung memang merupakan penggambaran sebenar dari jati diri Idris dan Pradi. Sehingga pengemasan sosok Idris dan Pradi sesuai dan memiliki unsur authentic yang akan berpengaruh pada psikologis audiens yang melihat laman tersebut.

2) Keunikan

Keunikan pasangan calon Walikota dan Wakil Walikota Idris-Pradi dapat dilihat dari keahlian, profesi dan intangible aspek seperti reputasi, budaya korporat hingga leadership.

Sosok Idris digambarkan sebagai sesuai keahlian dan kompetensinya di bidang Dakwah. Keseharian Idris yang juga sebagai Wakil Walikota pada masa Nur Mahmudi sudah teruji memberikan kontribusi dalam pembangunan kota Depok. Selain itu beliau juga merupakan dosen Fakultas Dakwah di UIN dan Universitas Indonesia.

Sosok Pradi juga digambarkan sebagai sosok muda yang memiliki jiwa leadership sebagai pengusaha muda sukses. Terlihat dari kompetensinya sebagai Ketua DPC Partai Gerindra 
kota Depok dan ESCO PSSI kota Depok.

\section{Jenis Pemilih pada Pilwakot Depok 2015}

Jenis pemilih pada Pilwakot Depok 2015 sebenarnya lebih kepada pemilih rasional, pemilih kritis, dan pemilih tradisional. Namun pemilih tradisional merupakan mayoritas dari pemilih yang ada. Karena pemilih dalam jenis ini berorientasi ideologi yang sangat tinggi dan tidak terlalu melihat kebijakan partai politik atau seorang kontestan sebagai sesuatu yang penting dalam pengambilan keputusan. Pemilih tradisional sangat mengutamakan kedekatan sosial budaya, nilai, asal-usul, paham dan agama sebagai ukuran untuk memilih sebuah partai politik. Di Indonesia pemilih jenis ini masih sangat mayoritas. Pasangan Calon Walikota dan Wakil walikota telah lama berinteraksi dengan masyarakat dinama Idris merupakan Incumbent (pertahana) yang telah menjabat sebagai wakil walikota pada periode sebelumnya dan Pradi merupakan sosok pemuda yang sukses dan memiliki jiwa kepemimpinan yang sudah dikenal di kota Depok.

\section{Efek Foto/Camera Branding Paslon Walikota dan Wakil Idris-Pradi}

Penggunaan media sosial dan internet yang dilakukan oleh tim sukses pasangan calon walikota dan wakil walikota Idris dan Pradi karena mengingat hampir 37.6\% warga Depok adalah usia produktif antara 20 tahun - 39 tahun $^{6}$. Dan rata-rata warga Depok pada usia tersebut akrab dan aktif menggunakan media sosial seperti Facebook dan Twitter sebagaimana yang dilansir viva.co.id bahwa $20,8 \%$ pengguna internet di tanah air sekitar 30 juta user

${ }^{6}$ Kota Depok dalam Angka 2015

mendaftar di Twitter dan 30,8\% pengguna Facebook ${ }^{7}$.

Selain itu efek penggunaan foto/camera branding dapat dilihat dari dapat terlihat dari siaran di MetroTv yang dilansir website www.idrispradi.com bahwa posting hashtag \#coblosnomor2idrispradi menjadi trending topik nomor tiga di Indonesia pada tahun 2015.

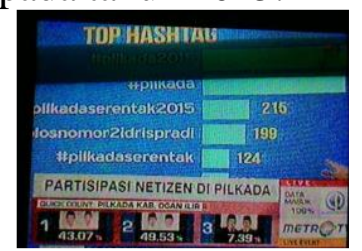

\section{Gambar 3. Top Hashtag pilkada 2015}

Menurut Steven M Chaffee dalam Ardianto (2007:50-58), efek penggunaan media dilihat dari tiga pendekatan, yaitu:

1) Efek Kognisi

Efek komunikasi politik pada penggunaan foto/camera branding pada kampanye PILWALKOT Idris-Pradi adalah audiens mendapatkan pemahaman terhadap siapa pasangann calon walikota dan wakil walikota Depok DR. H. M. IDRIS ABDUL SHOMAD, MA. dan Pradi Supriatna dapat diketahui melalui laman www.idrispradi.com pada pilihan profil paslon, 10 program kerja yang dicanangkan jika terpilih dan postingan kegiatan-kegiatan kandidat paslon dalam bentuk foto dan video.

2) Efek Afeksi

Efek afeksi yang muncul dari penggunaan foto/camera branding adalah munculnya dukungan terhadap paslon dari relawan-relawan yang diberi nama IP Man (Idris - Pradi Man). Relawan-relawan tersebut aktif mendukung paslon walikota dan wakil walikota dengan cara membuat fanspage di FB dan account twiter sebagai pendukung Idris dan Pradi.

\footnotetext{
${ }^{7}$ http://fokus.news.viva.co.id/news/read/170975indonesia-penguasa-situs-jejaring-sosial , diakses 2 Januari 2016.
} 


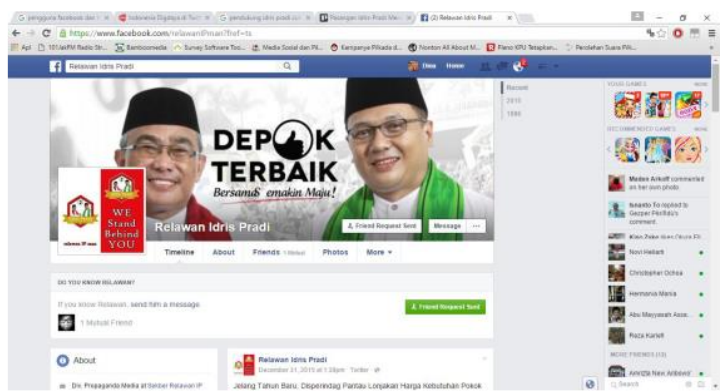

Gambar 4. Fanspage FB IP Man

3) Efek Behavioral

Efek Behavioral yang dilakukan partisipan/relawan Idris dan Pradi bermacam-macam, mulai dari pemberian dukungan suara dimana Idris-Pradi menang telak di tiga tempat pemungutan suara. Dapat dilihat dari perolehan suara yang dimenangi oleh paslon tersebut sebesar $58,01 \%$.

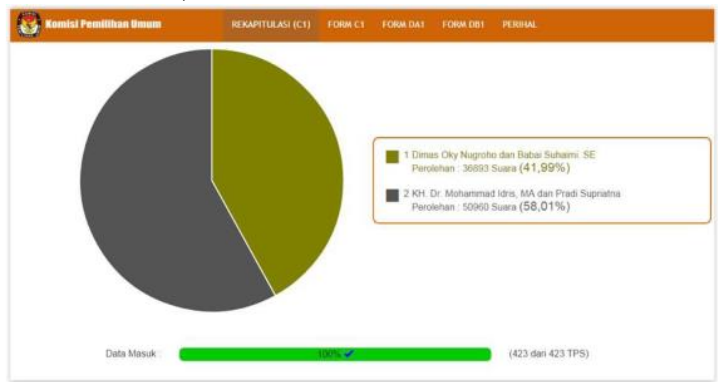

Gambar 5. Rekapitulasi Perolehan

Suara PILWAKOT DEPOK 2015

Dan efek behavioral yang cukup ekstrim dilakukan relawan-relawan IP Man dalam mendukung Idris-Pradi melalui mencukur rambut hingga habis setelah mengetahui bahwa paslon pilihannya menang sebagai Walikota dan Wakil walikota Depok 2015.

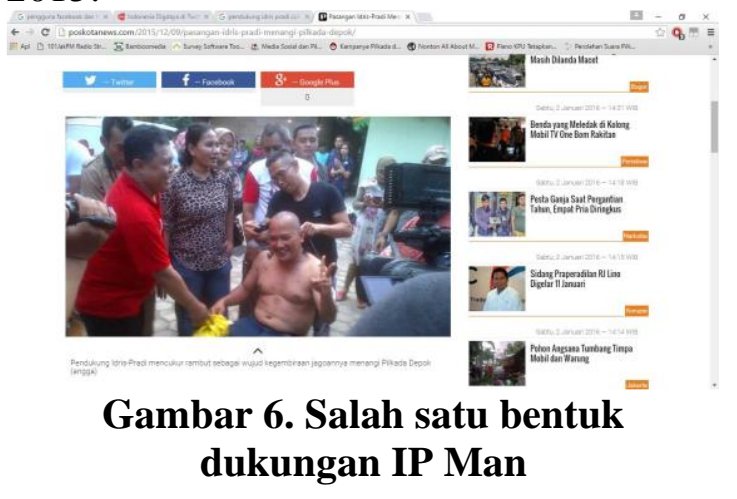

Sedangkan jika dilihat dari jenis efek yang timbul efek dari jangka waktu terdapat Short Term Effect yaitu efek jangka pendek yang berlangsung pada individu, group dan yang bersifat cepat dan sementara. seperti: opini mengenai paslon di media sosial twiter yang menjadi trending topik, adanya isu black campaign yang dilakukan paslon Idris-Pradi, serta terbentuknya relawan-relawan IP Man. Dan Long term effect yaitu efek komunikasi/komunikasi massa yang bersifat halus dan tersebar terhadap perilaku yang seolah-olah kurang diterima pengaruhnya, padahal justru menyangkut seluruh lingkingan masyarakat. Proses politik bukalah peristiwa singkat, melainkan peristiwa yang membutuhkan konstinuitas waktu jangka panjang. Kampanye politik dalam bentuk ini seperti kaderisasi, diklat, training dan lain-lain, yang dilakukan sebagai upaya untuk membentuk loyalitas khalayak (follower) terhadap partai.

\section{A. SIMPULAN}

Penerapan camera branding banyak dilakukan oleh paslon kepala daerah pada Pilkada langsung dan serentak di tahun 2015. Salah satu pemilihan yang menarik dan menjadi perhatian adalah pemilihan paslon walikota dan wakil walikota Depok. Pasangan nomor urut satu, Dimas Oky Nugroho dan Babai Suhaimini yang didukung PDI-P, PKB, PAN, Nasdem, dan Golkar. pasangan nomor urut dua, Idris Abdul Shomad dan Pradi Surpriyatna. Mereka mendapat dukungan dari PKS, NU, Gerindra, dan Demokrat. Bentuk-bentuk foto/camera branding dapat dilihat dari penggunaan pengambilan gambar mulai dari pengambilan gambar, sudut pandangan (angle) pengambilan gambar, tipe lensa yang digunakan, titik fokus yang digunakan, pencahayaan serta pewarnaan 
yang menonjol dalam foto. Selain itu elemen camera branding berupa elemen authentic dan elemen keunikan profil paslon juga mendukung tingkat elektabilitas.

Penggunaan foto/camera branding dapat menimbulkan efek langsung dan tidaklangsung bagi para pemilih. Dan pemilih di kota depok lebih kepada mayoritas tipe pemilih tradisional walaupun sekitar $37.6 \%$ pemilih di Kota Depok pada usia produktif.

\section{B. DAFTAR PUSTAKA}

Blair, T., \& Scammell, M. (2007). Political Brands and Consumer Citizens: The Rebranding of, (May), 176-192.

https://doi.org/10.1177/00027162062 99149

Cangara, H. (2009). Komunikasi Politik: Konsep, Teori dan Strategi. Jakarta: Rajawali Pers.

Darmawan, F. (2009). Dunia Dalam Bingkai. Yogyakarta.: Graha Ilmu.

Firmanzah. (2012). Marketing Politik: Antara Pemahaman dan Realitas (Revisi). Jakarta: Yayasan Pustaka Obor Indonesia. Retrieved from https://books.google.co.id/books?id= BE3pDQAAQBAJ\&printsec $=$ frontco ver\&dq=Firmanzah $+2007 \& h \mathrm{l}=\mathrm{id} \&$ sa $=X \& v e d=0$ ahUKEwiXgJ3imOnmAh WDIbcAHU4IBfIQ6AEIKDAA\# $\mathrm{v}=0$ nepage $\& \mathrm{q}=$ Firmanzah $2007 \& \mathrm{f}=$ false

Hidayat, D. N. (2003). Paradigma dan Metodologi Penelitian Sosial Empirik Klasik. Jakarta: Departemen Ilmu Komunikasi FISIP Universitas Indonesia.

Kasali, R. (2013). Camera Branding Cameragenic vs Auragenic. Jakarta: Gramedia Pustaka Utama. Retrieved from

https://www.goodreads.com/book/sh ow/17927909-camera-branding
Kriyantono, R. (2006). Teknik Praktis Riset Komunikasi. Jakarta: PT.Kencana Perdana.

Kusrianto, A. (2007). Pengantar Desain Komunikasi Visual. Yogyakarta: Andi Offset.

Moleong, L. J. (2011). Metodologi Penelitian Kualitatif (Edisi Revi). Bandung: PT. Remaja Rosdakarya.

Newman, B. I. (1999). Handbook of political marketing. Sage Publications.

Nursal, A. (2004). Political marketing: strategi memenangkan pemilu: sebuah pendekatan baru kampanye pemilihan DPR, DPD, Presiden. Jakarta: Gramedia Pustaka Utama.

Perse, E. M. (2000). Media effects and society. L. Erlbaum Associates.

Prisgunanto, I. (2006). Komunikasi Pemasaran: strategi dan taktik: Analisis Sostac dan Stopsit. Jakarta: Ghalia Indonesia.

Widyastuti, D. A., Wiloso, P. G., \& Herwandito, S. (2017). ANALISIS PERSONAL BRANDING DI MEDIA SOSIAL (Studi Kasus Personal Branding Sha'an d'Anthes di Instagram). Jurnalinovasi, 1-16. Retrieved from http://journal.binadarma.ac.id/index.p hp/jurnalinovasi/article/download/64 9/345

Yin, R. K. (2011). Studi Kasus: Desain dan Metode. Jakarta: Rajagrafindo Persada.

\section{Lainnya:}

\section{Daftar Referensi}

Peraturan KPU (PKPU) No. 70 Tahun 2015 tentang Pilkada Bab I Ketentuan Umum.

Kota Depok Dalam Angka 2015.

\section{Akses Website}

1. http://nasional.kompas.com/read/2015/0 9/25/15130071/Media.Sosial.Makin.Jad 
i.Primadona.Kampanye.Pilkada .

Diakses 11 Desember 2015.

2. http://www.bawaslu-

dki.go.id/13/10/2015/kampanye-

pilkada-di-media-sosial/ . diakses 11

Desember 2015.

3. http://www.depoknews.id/unggul-

survei-pilkada-depok-pradi-bersyukur/

diakses 18 Desember 2015.

4. http://fokus.news.viva.co.id/news/read/1

70975-indonesia-penguasa-situs-

jejaring-sosial. Diakses 2 Januari 2016.

\section{BIODATA PENULIS}

Dina Andriana, S.Sos, M.I.Kom

Lahir di Sungai Pakning, 21 April 1983.

Sebagai dosen tetap di Program Studi

Periklanan, Fakultas Komunikasi dan Bahasa

UBSI.

\section{Widarti, M.I.Kom}

Lahir di Jakarta, 21 Juni 1987, sebagai dosen tetap di Program Studi Periklanan dan anggota tim PPPM UBSI.

Jusuf Fadilah, M.I.Kom

Lahir di Jakarta, 9 Februari 1987, sebagai

Ketua Prodi Periklanan di Program Studi

Periklanan, Fakultas Komunikasi dan Bahasa

UBSI. 